九州大学学術情報リポジトリ

Kyushu University Institutional Repository

\title{
Digestion of Bloodmeal Protein after Detachment in Nymphal Haemaphysal is longicornis
}

Koh, Katsuki

Zoological Laboratory, Faculty of Agriculture, Kyushu University

Shiraishi, Satoshi

Zoological Laboratory, Faculty of Agriculture, Kyushu University

Uchida, Teruaki

Zoological Laboratory, Faculty of Agriculture, Kyushu University

https://doi.org/10.5109/23899

出版情報: 九州大学大学院農学研究院紀要. 34 (3)，pp.241-246，1990-02. Kyushu University バージョン：

権利関係 : 


\title{
Digestion of Bloodmeal Protein after Detachment in Nymphal Haemaphysalis longicornis
}

\author{
Katsuki Koh, Satoshi Shiraishi* and Teru Aki Uchida \\ Zoological Laboratory, Faculty of Agriculture, \\ Kyushu University 46-06, Fukuoka 812, Japan
}

(Received July 24, 1989)

\begin{abstract}
Changes in the digestive activity after detachment in nymphal Haemaphysalis Zongicornis were examined. The quantity of total protein decreased rapidly from the detachment day to the 9th day after detachment, and thereafter decreased slightly. The greater part of protein in the midgut was lost during the first 9 days. The major part of proteins in the midgut contents was hemoglobin and albumin. The quantity of hemoglobin was much larger than that of albumin at the detachment day, decreased rapidly until day 9 after detachment, and then was maintained at a low level. The quantity of albumin decreased at a constant rate which was conspicuously lower than that of hemoglobin. A large quantity of hematin was detected in the midgut at the detachment day. The quantity of hematin increased as hemoglobin digestion proceeded, and started to decrease rapidly from the 1st day after molting.
\end{abstract}

\section{INTRODUCTION}

In ticks, feeding is an important biological event for reproduction, especially for molting : therefore, studies of bloodmeal digestion may provide information on conversion of the bloodmeal into tick proteins. The rate of bloodmeal digestion in ticks has been determined mainly in females by means of the rate of decrease in hemoglobin in the midgut as a parameter (Kitaoka, 1961 ; O'Hagan, 1974 for Boophilus microplus; Tatchell, 1964 for Argas persicus; Akov et al., 1976 for Ornithodoros tholozani ; Araman, 1979 for Rhipicephalus sanguineus). Consequently, the digestive activity in detached females closely relates with the activity of egg production. On the other hand, the digestive activity in detached immature ticks, which relates with the activity of histogenesis toward the next stage, has been not yet determined, except for nymphal A. persicus.

Albumin is a major protein of other bloodmeal proteins besides hemoglobin, and accounts for $27 \%$ of total protein (Koh et al., 1989b). In this connection, tick protease regarded as cathepsin $\mathrm{D}$ in the midgut digests hemoglobin much better than albumin in the in vitro assays (Akov et al., 1976 for 0. tholozani). However, there is no in vivo study of albumin digestion in ticks. The purpose of our study was to examine changes in the digestive activity after detachment in nymphal H. Zongicornis, and to discuss relationships between the activity changes and the adult development, and in vivo properties of the tick protease.'

*To whom reprint requests should be addressed. 


\section{MATERIALS AND METHODS}

Tick source : Nymphs of H. longicornis derived from adults collected on a pasture in the Kujū highland, Oita Prefecture were starved for 40 days, and then fed on laboratory rabbits. Only engorged nymphs weighing 3.0-3.8 $\mathrm{mg}$ were used to select potential females, because nymphs weighing over $3.0 \mathrm{mg}$ produce females almost exclusively (Koh, unpublished). The upper limit of the body weight was fixed in order to minimize variations in the bloodmeal size. The nymphs were held individually in clean vials at $30 \pm 0.5^{\circ} \mathrm{C}$ and $100 \% \mathrm{RH}$ in a constantly dark incubator.

Collection of samples : On the detachment day and subsequent days until day 7 after molting, the midgut was dissected out in the cold saline, promptly frozen by means of liquid nitrogen, and then stored at $-95^{\circ} \mathrm{C}$ until analysis.

Fractionation of the midgut : The midgut was homogenized in cold $0.02 \mathrm{M}$ Tris- $\mathrm{HCl}$ buffer ( $\mathrm{pH} 7.5$ ), the suspension was centrifuged at $15,000 \mathrm{rpm}$ for $10 \mathrm{~min}$ at $4^{\circ} \mathrm{C}$, and the supernatant containing protein was recovered. The precipitate containing hematin was washed twice with the same buffer and dissolved in $0.1 \mathrm{M} \mathrm{NaOH}$.

Analytical methods : The quantity of protein was determined by the dye-binding method using commercially prepared dye reagent (Bio-Rad, CA, U. S. A.) with rabbit hemoglobin (Sigma) as a standard. Electrophoresis, SDS-PAGE, was done to separate the protein components, using acrylamide gradient (5-15\%) slab gel at a constant current $(30 \mathrm{~mA})$. After electrophoresis, the proteins were stained with Coomassie brilliant blue R250 (Katayama Chemical Industries Company, Osaka, Japan). Spectrophotometric scans of the gels were carried out to measure protein components using a densitometer (Shimadzu CS-930) at $560 \mathrm{~nm}$. The quantity of hematin was assayed by the pyridine hemochrome system (Falk, 1964), using hemin chloride (Sigma) as a standard and its millimolar extinction coefficient of 31.4 at $555.5 \mathrm{~nm}$.

\section{RESULTS}

Total protein : The quantity of total protein rapidly decreased from the detachment day $(D$ d) to day 9 after detachment $(D+9$ d), i. e. 1 day before molting $(M-1 d)$ and most of that was lost during the above period (Fig. 1). The rate of decrease reached a maximum between $\mathrm{D}+2 \mathrm{~d}$ and $\mathrm{D}+4 \mathrm{~d}$. Thereafter, the quantity of total protein declined slightly, but was still detectable at the end of this experiment $(\mathrm{M}+7$ d).

Protein components : The major part of proteins in the midgut contents was hemoglobin and albumin, and others which seemed to be midgut structural proteins were detected after $\mathrm{D}+9 \mathrm{~d}$ when most of total protein was lost. The quantity of hemoglobin was much larger than that of albumin at D d (Fig. 2). The quantity of hemoglobin remained unchanged during the first 2 days, decreased rapidly until D+ 9 $\mathrm{d}(\mathrm{M}-1 \mathrm{~d})$, and then was maintained at a low level. The rate of decrease reached a maximum between $\mathrm{D}+2 \mathrm{~d}$ and $\mathrm{D}+4 \mathrm{~d}$. On the other hand, the quantity of albumin 
decreased at a constant rate which was conspicuously lower than that of hemoglobin.

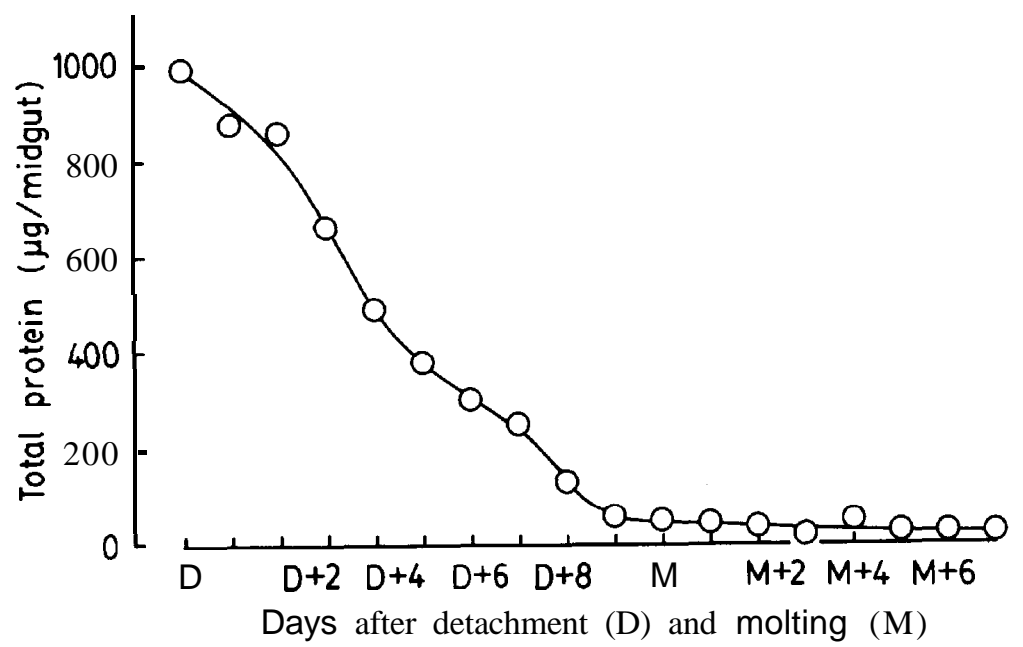

Fig. 1. Changes of total protein in the midgut after detachment in nymphal $H$. longicornis. Points indicate means for 5 individuals.

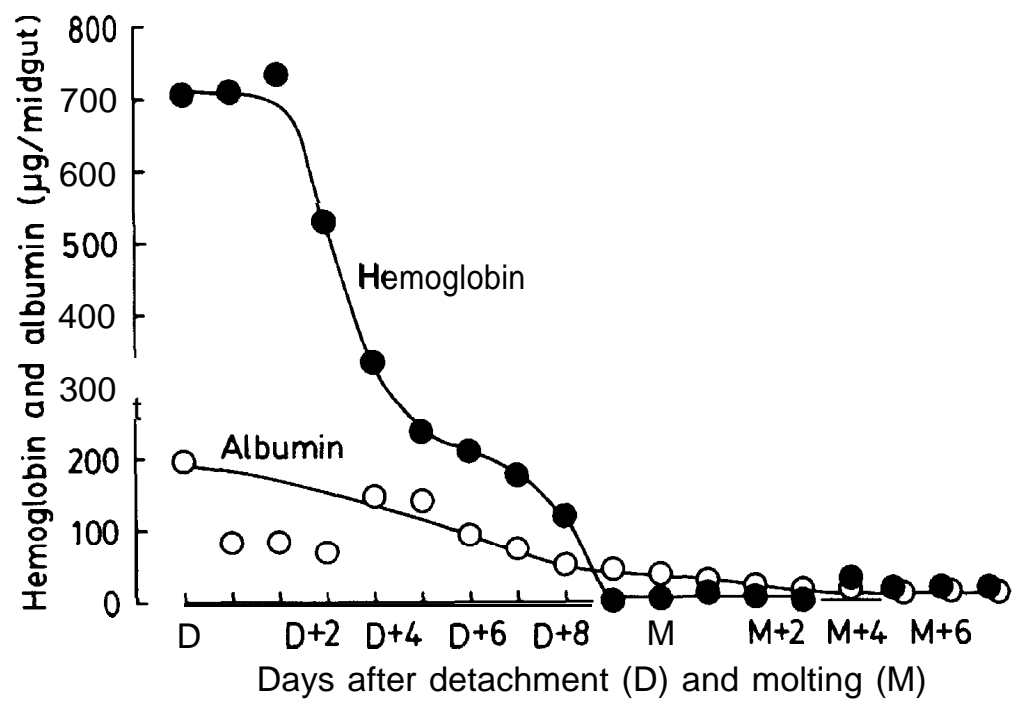

Fig. 2. Changes of hemoglobin and albumin in the midgut after detachment in nymphal $H$.longicornis. Points indicate means for 5 individuals.

Relationships between decrease of hemoglobin and increase of hematin : Hematin, a remnant of hemoglobin digestion, was detected in large quantities in the midgut at D d (Fig. 3). The quantity of hematin increased as that of hemoglobin decreased, reached a maximum at $\mathrm{M}+1 \mathrm{~d}$, and then reduced rapidly. Hematin was excreted for 3 days after $M+3 d$. 


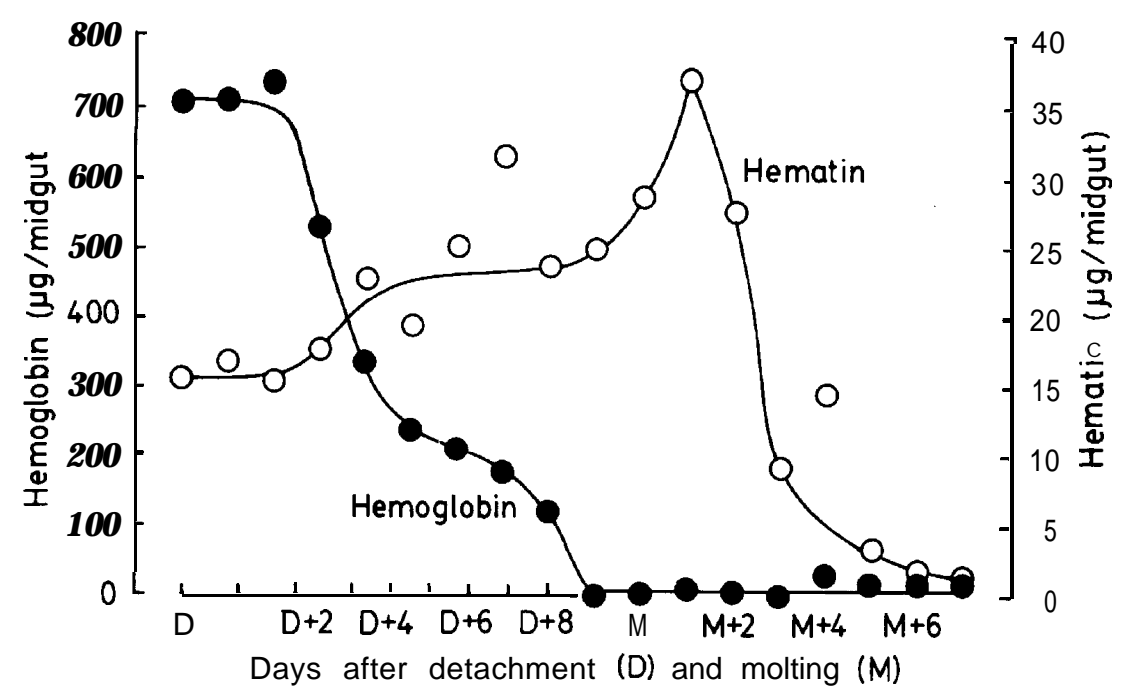

Fig. 3. Relationships between decrease of hemoglobin and increase of hematin in the midgut after detachment in nymphal $H$. longicornis. Points indicate means for 5 individuals.

\section{DISCUSSION}

The sequence of events in relation to protein digestion and synthesis in the female tick has been elucidated to some degree (Araman, 1979 for Rhipicephalus sanguineus) ; the digestive activity in the detached female synchronized with the activity of egg production, and most of protein in the midgut is digested before the end of the oviposition period. Amino acids and smaller peptides, both of which are digestive products, are transported to the fat body by hemolymph, and utilized by that organ to produce most of hemolymph proteins including vitellogenins. On the other hand, such a sequence has been scarcely investigated in nymphal ticks. This is the first report on changes in the digestive activity of detached nymphal ixodids.

A period of the high digestive activity in nymphal Haemaphysalis Iongicornis ceased at D+ $9 \mathrm{~d}(\mathrm{M}-1 \mathrm{~d})$, and most of protein in the midgut was lost during this period. Therefore, it seems that the high digestive activity reflects the greater need of amino acids and smaller peptides for molting, and that their quantity is equivalent to most of protein in the midgut. In this connection, it is suggested that the activity of protein synthesis in detached immature ticks reaches a high level during the second half of the premolting period (Belozerov, 1964 for Dermacentor marginatus and Ixodes ricinus). However, the rate of protein digestion in nymphal $\mathbf{H}$. Zongicornis was higher during the first half of the premolting period rather than during the second half. In order to explain this time lag, the processes of the protein synthesis from the digestive products should be examined also in nymphs.

Although the overall activity of protein digestion became conspicuously low after molting, successive decreases of albumin were found : accordingly, it was known that a certain degree of the digestive activity was still retained. Such organs as the cuticle, midgut, salivary gland and ovary are incomplete in recently molted ticks, and then are 
accomplished after the so-called postmolting development stage (Balashov, 1972). In this period, digestive cells in the midgut exhibit histological appearances of a little digestive activity (Balashov, 1972). Our results corresponded well with his histological findings. Postmolting development in adult $\mathbf{H}$. Zongicornis ceases on $\mathrm{M}+5 \mathrm{~d}$ at $30^{\circ} \mathrm{C}$, and then adults enter the unfed adult stage (Koh et al., 1989a). Therefore, it is assumed that the level of the digestive activity in newly molted females declined to that in unfed females after $M+5 \mathrm{~d}$.

The detached nymphs accumulated a large quantity of hematin in the midgut. The hematin is a remnant of hemoglobin digestion during feeding (Koh et al., 1989b). The quantity of hematin increased as hemoglobin digestion proceeded, and started to decrease rapidly after $M+1 \mathrm{~d}$. The decrease may be due to excretion of digestive cells filled with residual bodies (hematin) via the rectal sac, being supported by the findings that hematin was excreted only for 3 days after $\mathrm{M}+3 \mathrm{~d}$.

Tick protease in the midgut is considered to be cathepsin D from the viewpoint of the $\mathrm{pH}$ optimum, its substrate specificity and effects of inhibitors on the enzyme activity (Akov, 1982). Most importantly, hemoglobin is a more preferred substrate for cathep$\sin \mathrm{D}$ than albumin. Indeed, such phenomena are recognized also in the in vitro assays performed using the midgut homogenate including the enzyme (Akov et al., 1976 for Ornithodoros tholozani). In the present study, the fact that hemoglobin in the midgut was lost faster than albumin might be caused by the substrate specificity of the enzyme. Our study revealed for the first time the difference in the in vivo digestion rate of the two proteins, suggesting that the enzyme in the homogenate used in the above in vitro assays contributes to in vivo digestion. As for albumin, there remained as much as hemoglobin in the midgut of unfed adult (this study) and nymphal (Koh et al., 1989b) H. Zongicornis on account of the low digestion rate. Consequently, albumin seems to be utilized as a food reserve in H. Zongicornis.

In conclusion, nymphal $\mathbf{H}$. Zongicornis consumes most of protein in the midgut in molting for 9 days at $30^{\circ} \mathrm{C}$, and hemoglobin is digested faster than albumin as well as in vitro, owing to the substrate specificity of the midgut protease.

\section{ACKNOWLEDGEMENTS}

We thank Dr. Y. Kawaguchi, Professor 0. Koga, Dr. N. Fujihara and Dr. T. Mōri, Faculty of Agriculture, Kyushu University, and Professor T. Omura, Graduate School of Medical Science, Kyushu University, for permission to use analytical instruments and for valuable suggestions ; and Professor E. W. Jameson, Jr., University of California, for comments on the manuscript. This work was supported in part by a Grant-inAid from the Ministry of Education, Science and Culture, Japan.

\section{REFERENCES}

Akov, S. 1982 Bloodmeal digestion in ticks. In "Physiology of Ticks", ed. by F. D. Obenchain and R. Galun, Pergamon Press, Oxford, pp. 197-211

Akov, S., M. Samish and R. Galun 1976 Protease activity in female Omithodoyos tholozani ticks. Acta Trop., 18: 37-52

Araman, S. F. 1979 Protein digestion and synthesis in ixodid females. In "Recent Advances in Acarology", Vol. 1, ed. by J. Rodriguesz, Academic Press, New York, pp. 385-395

Balashov, Yu. S. 1972 Bloodsucking ticks (Ixodoidea). Vectors of diseases of man and animals. 
Misc. Publ. Ent. Soc. Am., 8: 161-376

Belozerov, V. N. 1964 Dynamics of gas exchange during the development of ixodid ticks. 1. Dynamics of gas exchange in the larval and nymphal stages of Dermacentormarginatus Sulz. and Ixodes ricinus (L.) (Acarina, Ixodidae). Entomol. Rev., 43 : 288-292

Falk, J. E. 1964 Haems. In "Porphyrins and Metalloporphyrins : Their General, Physical Coordination Chemistry, and Laboratory Methods", Elsevier, Amsterdam, pp. 181-188

Kitaoka, S. 1961 Physiological and ecological studies on some ticks. VI. Rate of digestion of blood meal and nitrogen, iron, and sterol economy during the ovipositing process in the tick. Nat. Inst. Anim. Hlth Q uart., 1: 105-112

Koh, K., S. Shiraishi and T. A. Uchida 1989a Physiological phases of nymphal molting defined by mobility, body weight decrease, and excretion in Haemaphysalis longicomis (Acari : Ixodidae). $J$. Med. Entomol., 26: 77-80

Koh, K., S. Shiraishi and T. A. Uchida 1989b Accumulation, digestion and excretion of bloodmeal protein during feeding in nymphal Haemaphysalis Longicomis. J.Fac. Agr., Kyushu U niv., 34 : 107114

O'Hagan, J. E. 1974 Boophilus microplus : digestion of hemoglobins by the engorged female tick. Exp.Parasitol., 35: 110-118

Tatchell, R. J. 1964 Digestion in the tick, Argas persicus, Oken. Parasitology, 54 : 423-440 